\title{
PENGARUH TOTAL ASSET TURNOVER (TATO), PRICE BOOK VALUE (PBV), DEBT TO EQUITY RATIO (DER) DAN RETURN ON EQUITY (ROE) TERHADAP RETURN SAHAM
}

\author{
Siti Dini'1), Yunus Anugerah Hulu' ${ }^{2}$, Meltin Zebua ${ }^{3)}$, Elisno Purba ${ }^{4)}$ \\ Universitas Prima Indonesia, Medan, Indonesia ${ }^{1}$ \\ Email : siti.dni@gmail.com ${ }^{1}$
}

\begin{abstract}
ABSTRAK
Tujuan dilakukan penelitian ini guna menunjukkan seberapa besar secara simultan dan parsial TATO, PBV, DER dan ROE memberikan pengaruh terhadap Return saham pada perusahaan restoran, hotel dan pariwisata yang terdaftarkan di Bursa Efek Indonesia tahun 2015-2019. Penelitian ini menggunakan pendekatan kuntitatif dan jenis penelitian statistika deskriptif. Uji statistika menggunakan SPSS 25. Jenis data penelitian menggunakan data sekunder. Metode pengambilan sampelnya menggunakan Purposive Sampling serta total sampel didapatkan 17 perusahaan dan jumlah observasi diperoleh 85 data. Hasil penelitian memperlihatkan TATO,PBV, DER dan ROE tidak memberikan pengaruh serta tidak tidak signifikan secara parsial terhadap Return Saham pada perusahaan restoran, hotel dan pariwisata. Sedangkan secara simultan TATO, PBV, DER dan ROE tidak memberikan pengaruh dan tidak signifikan terhadap Return Saham pada perusahaan restoran, hotel dan pariwisata yang terdaftarkan pada Bursa Efek Indonesia tahun 2015-2019.
\end{abstract}

Kata Kunci : TATO, PBV, DER, ROE, Return Saham.

\begin{abstract}
The purpose of this research is to show how much simultaneously and partially TATO,PBV, DER and ROE have an influence on stock returns in restaurant, hotel and tourism companies listed on the Indonesia Stock Exchange in 2015-2019. This research uses a quantitavive approach and descriptive statistical research type. Statistical test using SPSS 25. This type of research data using secondary data. The sampling method used purposive sampling and a total sample of 17 companies was obtained and the number of observations obtained was 85 data. The result showed that TATO, PBV, DER and ROE did not have an effect and were not partially significant towards stock return in restaurant, hotel and tourism companies. Meanwhile, simultaneously TATO, PBV, DER and ROE do not have a significant effect on the return of share in restaurant, hotel and tourism companies listed on the Indonesia Stock Exchange in 2015-2019.
\end{abstract}

Keywords : TATO, PBV, DER, ROE, Stock Return. 


\section{PENDAHULUAN}

Perkembangan perekonomian zaman sekarang menghadapi kemajuan cukup besar seiring dengan berjalannya waktu terutama di dalam pasar modal. Berkembang-nya pasar modal yang cukup besar membuat investor berlombalomba melakukan aktivitas investasi pada Bursa Efek Indonesia (BEI) dalam mendapatkan return yang lebih tinggi atas hasil deviden yang dimilikinya (Muklis, 2016). Para investor yang akan menanamkan modalnya terlebih dahulu akan meninjau dan menilai kemampuan perfoma perusahaan yang dijadikannya tempat investasi serta para investor pastinya akan berinvestasi terhadap perusahaan yang mempunyai perfoma baik sehingga mendapatkan keuntungan dari penanaman modal yang telah dilakukannya dan terhindar dari resiko seminim mungkin. Para investor akan lebih selektif dalam memilih perusahaan tempatnya menanamkan modal. Perfoma suatu perusahaan dapat di amati pada laporan keuangan yang telah dipublikasikandi situs resmi BEI. Investor yang melakukan penanaman modal pastinya membutuhkan suatu perencanaan yang baik dan strategis. Karena investor tidak dapat memperkirakan profit yang akan diterima oleh investor. Oleh karena itu para investor memiliki cara dalam menganalisa return saham suatu perusahaan dengan cara menganalisa beberapa rasio keuangan perusahaan. Cara perhitungan ini bertujuan untuk mengetahui kelebihan dan kelemahan perusahaan serta memastikan perusahaan tersebut dalam kondisi perfoma baik/tidak. Laporan keuangan amat berperan besar dalam memberikan informasi kepada penggunanya terutama bagi para investor (Mandika, 2017). Dalam menganalisis laporan keuangan, rasio yang sering kali digunakan untuk menjadi tolak ukur seorang investor dalam melihat perusahaan tersebut baik atau tidak adalah rasio aktivitas, profitabiltas, solvabilitas,serta rasio pasar.

Rasio aktivitas di pergunakan dalam menilai seberapa jauh keefektifan perusahaan di dalam memakai sumber daya yang dimilikinya. Salah satu rasio aktivitas yang kerap kali dipergunakan oleh pengguna informasi laporan keuangan dalam mengetahui mungkinkah perusahaan tersebut sudah efektif dalam memanfaatkan sumber dayanya dilihat dari Total Asset TurnOver (TATO) yang dimana rasio ini menunjukkan sejauh mana kekuatan seluruh aktiva dalam mewujudkan sales. Rasio solvabilitas dipakai untuk menilai suatu perusahaan dalam melunasi keseluruhan hutangnya. Salah satu rasio solvabilitas yang biasa digunakan dalam menjadi tolak ukur sebuah perusahaan dalam menbayar hutangnya dilihat pada debt to equity ratio ( DER ) dimana menggambarkan tolok ukur antar jumlah utang dengan ekuitas perusahaan. Rasio profitabilitas dipakai untuk menujukkan kekuatan sebuah perusahaan dalam mendapatkan laba/profit. Salah satu komponen profitabilitas yang pada umumnya di gunakan apakah perusahaan tersebut mengalami laba atau tidaknya dari hasil pengembalian ekuitas (return on equity) dimana dipakai dalam menilai seberapa jauh kemampuan perusahaan didalam mendapatkan profit bagi investor perusahaan dengan modal sendiri. Rasio 
terakhir ialah rasio pasar dimana rasio ini digunakan untuk memperlihtakan sepanjang manakah investor saham menilai layak tidaknya harga saham suatu perusahaan untuk dibeli. Rasio pasar yang sering kali dipergunakan ialah Price Book Value (PBV) dimana PBV ini memperlihatkan bandingan antar harga saham dengan nilai buku ekuitas. Populasi penelitian yakni semua Perusahaan Restoran, Hotel dan Pariwisata dan terdaftarkan pada BEI dengan pengamatan 5 tahun mulai dari 20152019. Sektor perusahaan ini adalah salah satu perusahaan yang mempunyai kekuatan tinggi dalam membantu roda perekonomian sekaligus menjadi kekuatan pengembangan perekonomian Indonesia.

Berdasarkan berita pada kompas.com di tanggal 27 september 2018 (https://ekononomi.kompas.com) dikatakan bahwa investasi Sektor Restoran dan Hotel penanaman modal nya sebesar 69.9\% , jasa Pariwisata sebesar 23.3\% serta kawasan pariwisata sebesar 0.9\% pada tahun 2018. Realisasi di 2015 dan 2016 terjadi peningkatan baik penanaman modal dalam negeri (PMDN) mau pun penanaman modal asing (PMA) tetapi pada 2016 -2017 pernah mengalami penurunan. Besaran realisasi investasi pada tahun 2015 senilai RP 900 M (PMDN) dan PMA sebesar 2,5 trilliun dan jumlah keseluruhan realisasinya Rp 3,45 trilliun. Sedangkan pada 2016 realisasi Penanaman Modal dalam Negeri sebesar Rp 779 M, Penanaman Modal Asing senilai Rp 10,5 trilliun mka jumlah keseluruhannya sebesar Rp 11,3 trilliun. Akan tetapi, pada tahun 2017 cukup mengalami penurunan realisasi investasi sebesar 6,26 trilliun PMA tetapi PMDN naik sebesar Rp 3,2 trilliun maka jumlah keseluruhan realisasinya sebesar Rp 9,5 trilliun. Sedangkan di 2018 realisasi PMDN sebesar Rp 3,23 trilliun dan PMA sebesar Rp 2,68 trilliun dimana pada waktu itu baru saja menyelesaikan semesternya 1-nya.

Total Asset Turnover (TATO) merupakan salah satu rasio aktivitas yang digunakan dalam menunjukkan hubungan antara penjualan netto dengan aktiva tetap. Rasio ini yang menunjukkan berapa kali dana yang ditanamkan dalam aktiva tetap berputar salam satu periode. TATO adalah rasio yang dipergunakan untuk mengukur efisiensi suatu perusahaan dan mengatur aktiva tetap serta menunjang kegiatan penjualan dalam suatu perusahaan (Andasari, 2016).

Price book value (PBV) merupakan salah satu rasio pasar yang dipergunakan dalam mengukur kinerja harga pasar saham terhadap nilai bukunya. PBV ditunjukkan sebagai perbandingan antara harga saham terhadap pendapatan per lembar saham. Rasio PBV menunjukkan seberapa jauh kemampuan suatu perusahaan menciptakan nilai perusahaan relative terhadap jumlah modal yang diinvestasikan sehingga makin tinggi PBV maka menunjukkan keberhasilan perusahaan menciptakan nilai bagi pemegang saham (Puspitasari, 2012)

Debt to Equity Ratio (DER) merupakan rasio Solvabilitas yang digunakan dalam mengukur kemampuan modal sendiri perusahaan untuk dijadikan sebagai jaminan utang perusahaan. Debt to Equity Ratio merupakan bagian dari solvabilitas yang diartikan sebagai rasio yang dipergunakan dalam menilai hutang dengan 
ekuitas. DER mengukur besar kecilnya pemanfaatan utang dibandingkan modal sendiri perusahaan. Besarnya hutang yang terdapat dalam struktur modal perusahaan sangat penting untuk memahami perbandingan antara risiko dan profit yang didapat perusahaan. Perusahaan yang mempunyai DER tinggi mencerminkan risiko keuangan perusahaan tersebut semakin besar dikarenakan utang akan menimbulkan keterikatan yang tetap bagi perusahaan berupa kewajiban untuk membayar beban bunga beserta cicilan kewajiban pokok periodic, dibandingkan dengan perusahaan yang mempunyai DER rendah. Berdasarkan teori agensi, tingkat penggunaan utang yang tinggi cenderung mengurangi pengungkapan tanggung jawab social yang dibuat oleh perusahaan supaya tidak menjadi sorotan dari para debtholders (Sudana, 2011).

Return On Equity (ROE) merupakan salah satu rasio profitabilitas yang dipergunakan dalam mengukur seberapa besar laba bersih yang dapat dihasilkan dari modal yang diinvestasikan oleh pemegang saham. ROE adalah rasio laba bersih terhadap ekuitas, mengukur tingkat pengembalian atas investasi. ROE menggambarkan sejauh mana kemampuan suatu perusahaan dalam menghasilkan laba yang dapat diperoleh pemegang saham. ROE yang tinggi memperlihatkan kinerja perusahaan baik sehingga bisa menghasilkan keuntungan yang lebih tinggi. Hal tersebut menarik minat para investor untuk berinvestasi sebab menggangap bahwa perusahaan yang memberikan pengembalian yang tinggi pula. Sedangkan perusahaan yang memiliki ROE rendah menunjukkan tingkat pengembalian yang rendah dan memperliharkan kinerja perusahaan buruk dalam menghasilkan profit (Rajagukguk, 2018)

Return Saham merupakan hasil yang diperoleh dari suatu investasi. Return saham dapat dibedakan menjadi 2 yakni return realisasi (realized return) dan return ekspektasi (expected return). Return realisasi adalah return yang telah terjadi yang dihitung berdasarkan data historis serta return ini berperan penting dimana mengukur kinerja perusahaan dan sebagai dasar penentuan return dan risiko dimasa akan datang (mendatang) sedangkan return ekspektasi adalah return yang diharapkan dimasa mendatang dan bersifat tidak pasti. Dalam melakukan investasi , investor dihadapkan pada ketidakpastian anatar return yang akan diterima dengan risiko yang akan dihadapinya. Semakin tinggi return yang diharapkan dari investasi, maka makin tinggi pula risikonya sehingga dapat dikatakan bahwa return ekspektasi memiliki hubungan positif dengan risiko. Biasanya risiko yang tinggi dikorelasikan dengan peluang untuk memperoleh return yang lebih tinggi pula, akan tetapi return yang tinggi tidaklah selalu disertai dengan investasi yang berisiko. Return saham merupakan dokumen sebagai bukti kepemilikan suatu perusahaan. Apabila perusahaan mendapatkan keuntungan , maka setiap pemegang saham berhak atas laba yang dibagikan sesuai dengan proporsi kepemilikan (Bisara, 2015). 


\section{METODE PENELITIAN}

Populasi dalam penelitian ini adalah perusahaan Restoran, Hotel dan Pariwisata yang terdaftar di Bursa Efek Indonesia (BEI) tahun 2015-2019. Jumlah populasinya sebanyak 35 perusahaan. Sampel yang digunakan dalam penelitian ini adalah perusahaan restoran, hotel dan pariwisata yang terdaftarkan pada BEI dalam kurun waktu pengamatan 2015-2019 serta perusahaan restoran, hotel dan pariwisata yang tidak mempublikasikan laporan keuangan tahunannya secara beruntun pada tahun 2015-2019 dengan menggunakan teknik Purposive Sampling sehingga didapat sampel sebanyak 85 data. Data yang digunakan dalam penelitian adalah data sekunder.

Dalam model penelitian ini menggunakan analisis liner linear berganda. Menurut Sanusi (2014:134-135) menyatakan linear berganda ialah perkembangan dari linear sederhana dimana memperbanyak hasil variabel independen sebelumnya satu menjadi dua / lebih variabel independen.

\section{HASIL DAN PEMBAHASAN}

\section{Statistika Deskriptif}

Data dalam telaah sebanyak 85 sampel, namun hasil setelah dilakukan persamaan regresi linear berganda dan transformasi data dinyatakan tidak normal dikarenakan ditemukannya data yang memiliki nilai ekstrim sehingga dilakukan uji outlier. Hasil uji outlier diperoleh sebanyak 57 sampel. Berikut ini adalah hasil output statistika deskriptif.

Tabel 1 Statistika Deskriptif

\begin{tabular}{l|r|r|r|r|r} 
& \multicolumn{6}{c}{ Statitiska Deskriptif } \\
\hline TATO & $\mathrm{N}$ & Minimum & Maximum & \multicolumn{1}{c}{ Mean } & Std. Deviation \\
\hline PBV & 57 & .010 & 1.929 & .37673 & .411185 \\
\hline DER & 57 & .064 & 2446.600 & 156.78491 & 454.955675 \\
\hline ROE & 57 & .010 & 1.951 & .67226 & .441170 \\
\hline RETURN SAHAM & 57 & .000 & .205 & .05513 & .050706 \\
\hline Valid N (listwise) & 57 & -.932 & 1.164 & -.03800 & .437562 \\
\hline
\end{tabular}

Sumber : data Diolah

Sesuai hasil uji statistika variabel Return saham nilai minimum adalah senilai $-0.932 \%$ didapat dari perusahaan Red Planet Indonesia Tbk (PSKT) dan maximum senilai $1.164 \%$ didapat dari perusahaan KPIG. Selanjutnya rata-rata (mean) senilai $-0.03800 \%$ serta hasil standar deviasinya senilai $0.437562 \%$. Berdasarkan pengujian statistik variabel TATO $\left(\mathrm{X}_{1}\right)$ diketahui bahwa minimum senilai $0.010 \%$ dimiliki oleh PT Hotel Mandarine Regency Tbk (HOME) serta nilai maximum senilai $1.929 \%$ terdapat di perusahaan BAYU. Mean senilai $0.37673 \%$ dengan standar 
deviasi senilai $0.411185 \%$. Pengujian variabel PBV $\left(\mathrm{X}_{2}\right)$ diketahui nilai minimum sebesar $0.064 \%$ terdapat pada perusahan PT Pembangunan Graha Lestari Indah Tbk (PGLI) dan nilai maximum sebesar $2446.600 \%$ terdapat pada perusahaan PT Pioneerindo Gourment International Tbk (PTSP). Nilai mean sebesar 156.78491\% dengan standar deviasi sebesar $454.955675 \%$. Berdasarkan pengujian statistik variabel DER $\left(\mathrm{X}_{3}\right)$ diketahui nilai terkecil (min) senilai $0.010 \%$ terdapat di perusahaan PGLI serta nilai maximum senilai 1.951\% terdapat di perusahaan PJAA. Mean senilai $0.67226 \%$ dan standar deviasi senilai $0.441170 \%$. Berdasarkan pengujian statistika variabel ROE $\left(\mathrm{X}_{4}\right)$ diketahui minimum senilai $0.000 \%$ terdapat pada PT Panorama Sentrawisata Tbk (PANR) serta nilai maximum senilai $0.205 \%$ terdapat pada perusahaan Red Planet Indonesia Tbk (PSKT). Nilai mean senilai 0.05513\% dengan standar deviasinya senilai $0.050706 \%$.

\section{Hasil Uji Asumsi Klasik Uji Normalitas}

Tujuan pengujiannya ialah apakah didalam permodelan regresi yang dilakukan di temukan variabel residual memiliki distribusi normal/ tidak (Ghozali, 2016:154). Salah satu Metode uji normalitas yakni analisis statistik dengan melakukan pengujian Kolmogorov smirnov dan sig > 0,05 berarti memiliki data normal.

Tabel 2 One Sample Kolmogorov-Smirnov

One-Sample Kolmogorov-Smirnov Test

\begin{tabular}{llc} 
& & Unstandardized Residual \\
\hline $\mathrm{N}$ & & 57 \\
\hline Normal & Mean & .0000000 \\
\cline { 2 - 3 } Parameters ${ }^{\mathrm{a}, \mathrm{b}}$ & Std. Deviation & .43463931 \\
\hline Most Extreme & Absolute & .116 \\
\cline { 2 - 3 } Differences & Positive & .116 \\
\cline { 2 - 3 } & Negative & -.063 \\
\hline Test Statistic & & .116 \\
\hline Asymp. Sig. (2-tailed) & $.054 \mathrm{c}$ \\
\hline
\end{tabular}

Sumber : Data Diolah

Sesuai hasil di Tabel 2 dimana di peroleh signifikan senilai $0.054>0,05$ oleh karena itu asumsi normalitas terpenuhi.

\section{Uji Multikolonieritas}

Tujuan pengujian yakni memperlihatkan apakah didalam permodelan yang dilaksanakan terdapat korelasi pada variabel bebas (Ghozali, 2016:103-106). Jika angka tolerance menunjukkan $\leq 0,10$ serta angka VIF $\geq 10$ berarti memperlihatkan gejala multikolonieritas. 
Tabel 3 Pengujian Multikolonieritas

\begin{tabular}{ll|l|l|} 
& & \multicolumn{3}{|c}{ Collinearity Statistics } \\
Model & Tolerance & VIF & \\
\hline 1 & (Constant) & & \\
\cline { 2 - 5 } & TATO & .334 & 2.992 \\
\cline { 2 - 5 } & PBV & .430 & 2.325 \\
\cline { 2 - 5 } & DER & .668 & 1.498 \\
\cline { 2 - 5 } & ROE & .893 & 1.119 \\
\hline
\end{tabular}

a. Dependent Variable: RETURN SAHAM

Sumber : Data Diolah

Hasil yang didapat tiap variabel independen TATO, PBV, DER dan ROE memiliki nilai tolerance diatas 0,10 sedangkan nilai VIF-nya dibawah 10 berarti dinyatakan TATO, PBV, DER serta ROE tidak terdapat gejala multikolonieritas.

\section{Uji Autokorelasi}

Pengujian ini bertujuan menunjukkan mungkinkah didalam permodelan regresi didapat korelasi diantara kesalahan penggangu periode $t$ dengan $t-$ 1sebelumnya (Ghozali, 2018:112). Uji ini memakai nilai Durbin Watson (DW) sertanya kriteria $\mathrm{du}<\mathrm{d}<\mathrm{d}<4$-du artinya tiada ditemukan autokerelasi

Tabel 4 Pengujian Autokorelasi

\begin{tabular}{|c|c|c|c|c|c|}
\hline \multicolumn{6}{|c|}{ Model Summary } \\
\hline Model & $\mathrm{R}$ & R Square & $\begin{array}{l}\text { Adjusted R } \\
\text { Square }\end{array}$ & $\begin{array}{l}\text { Std. Error of the } \\
\text { Estimate }\end{array}$ & Durbin-Watson \\
\hline 1 & $.115^{\mathrm{a}}$ & .013 & -.063 & .451047 & 2.167 \\
\hline
\end{tabular}

Sumber : Data Diolah

Dari pengujian DW di Tabel 4 menunjukkan angka DW sebesar 2.167 dengan tingkat signifikan 5\%) dengan total $\mathrm{N}=57$, didapat nilai du $=1.725$ serta $\mathrm{dl}=1.4264$. Melalui kriteria DW didapat nilai $1.725<2.167<2.248$ sehingga menunjukkan bahwa terbebas dari autokorelasi.

\section{Uji Heterokedastisitas}

Pengujian ini bermaksud mengetahui mungkinkah didalam permodelan regresi terdapat ketikcocokkan variance dari satu pengamat ke pengamat lain (Ghozali, 2016:134) . Uji ini memakai metode yakni scatterplot yang mana titik-titik bertebaran serta tersebar acar dibawah mapun di atas dari nilai 0 ke sumbu Y berarti menunjukkan tak ada gejala heterokedasitisitas dan uji gletser , apabila nilai sig > 5\% maka tidak ditemukan heterokedastisitas 
Tabel 5 Uji Gletser

\begin{tabular}{|c|c|c|c|c|c|c|}
\hline \multirow{2}{*}{\multicolumn{2}{|c|}{ Model }} & \multicolumn{2}{|c|}{ Unstandardized Coefficients } & \multirow{2}{*}{$\begin{array}{c}\text { Standardized Coefficients } \\
\text { Beta }\end{array}$} & \multirow[b]{2}{*}{$\mathrm{t}$} & \multirow[b]{2}{*}{ Sig. } \\
\hline & & $\mathrm{B}$ & Std. Error & & & \\
\hline 1 & (Constant) & .395 & .077 & & 5.102 & .000 \\
\hline & TATO & -.113 & .164 & -.161 & -.687 & .495 \\
\hline & PBV & $-2.337 \mathrm{E}-6$ & .000 & -.004 & -.018 & .986 \\
\hline & DER & -.034 & .108 & -.052 & -.310 & .758 \\
\hline & ROE & -.118 & .814 & -.021 & -.144 & .886 \\
\hline
\end{tabular}

a. Dependent Variable: ABS_RES

Sumber : Data Diolah

Sesuai uraian di Tabel 5 nilai Uji Gletser menyatakan hasil signifikan dari variabel indepen TATO, PBV, DER dan ROE > 0,05 maka ditarik kesimpulan dalam pengujian ini ialah tidak terdapat gejala heterokedastisitas.

\section{Hasil Analisis Data}

\section{Regresi Linear Berganda}

Tabel 6 Persamaan Regresi Linear Berganda

\begin{tabular}{|c|c|c|c|c|c|c|c|}
\hline \multirow[b]{2}{*}{ Model } & $\begin{array}{r}\text { Unsta } \\
\mathrm{Co}\end{array}$ & $\begin{array}{l}\text { lardized } \\
\text { cients }\end{array}$ & \multirow{2}{*}{$\begin{array}{l}\text { Coefficien } \\
\text { Standardize } \\
\mathrm{d} \\
\text { Coefficients } \\
\text { Beta } \\
\end{array}$} & \multirow[b]{2}{*}{$\mathrm{t}$} & \multirow[b]{2}{*}{ Sig. } & \multicolumn{2}{|c|}{ Collinearity Statistics } \\
\hline & $\mathrm{B}$ & Std. Error & & & & Tolerance & VIF \\
\hline 1 (Constant) & -.004 & .120 & & -.037 & .971 & & \\
\hline TATO & .110 & .254 & .103 & .433 & .667 & .334 & 2.992 \\
\hline PBV & $-2.354 \mathrm{E}-5$ & .000 & -.024 & -.117 & .908 & .430 & 2.325 \\
\hline DER & -.031 & .167 & -.031 & -.185 & .854 & .668 & 1.498 \\
\hline ROE & -.915 & 1.258 & -.106 & -.728 & .470 & .893 & 1.119 \\
\hline
\end{tabular}

a. Dependent Variable: RETURN SAHAM

Sumber : Data Diolah

Hasil dari konstanta (a) senilai 0.004 , maksudnya jika variabel TATO, PBV, DER dan ROE senilai nol, dengan demikian return saham ialah sebesar 0.004 .

Nilai koefisien TATO senilai 0.110 berarti memperlihatkan bahwa tiap terjadi kenaikan TATO sekali, dengan demikian return saham terjadi penambahan senilai 0.110. Nilai koefisien variabel PBV senilai -2.354E-5 hal ini memperlihatkan tiap terjadi penurunan PBV sekali, dengan demikian return saham terjadi pengurangan senilai -2.354E-5. Nilai koefisien variabel DER senilai -0.031 hal ini memperlihatkan setiap mengalami penurunan DER sekali, dengan demikian Return Saham akan terjadi pengurangan senilai -0.031 .

Hasil koefisien variabel ROE senilai -0.915 maka memperlihatkan tiap terjadi penurunan ROE sekali dengan demikian return saham terjadi penurunan senilai 0.915.

\section{Koefiesien Determinasi}

Pengujian ini bertujuan untuk menilai kemampuan kekuatan permodelan regresi dalam menguraikan varian variabel dependen. 
Tabel 7 Koefisien Determinasi

\begin{tabular}{|c|c|c|c|c|}
\hline \multirow[b]{2}{*}{ Model } & \multirow[b]{2}{*}{$\mathrm{R}$} & \multirow[b]{2}{*}{ R Squre } & \multicolumn{2}{|l|}{ Model Summary } \\
\hline & & & Adjusted R Square & Std. Error of the Estimate \\
\hline 1 & $.115^{\mathrm{a}}$ & .013 & -.063 & .451047 \\
\hline
\end{tabular}

Pada Tabel 7 terlihat bahwa $R$ Square senilai 0.013 berarti dapat dijelaskan bahwa return saham senilai 0.013 atau $1.3 \%$ oleh variabel TATO, PBV, DER, ROE dan 98.7\% dipengaruhi atau disebabkan oleh variabel lainnya.

Uji t

Pengujian ini dipergunakan dalam memperlihatkan sejauh mana satu variabel penjelas/individu memberikan pengaruh terhadap variabel terikat.

Tabel 8 Pengujian $\mathrm{t}$

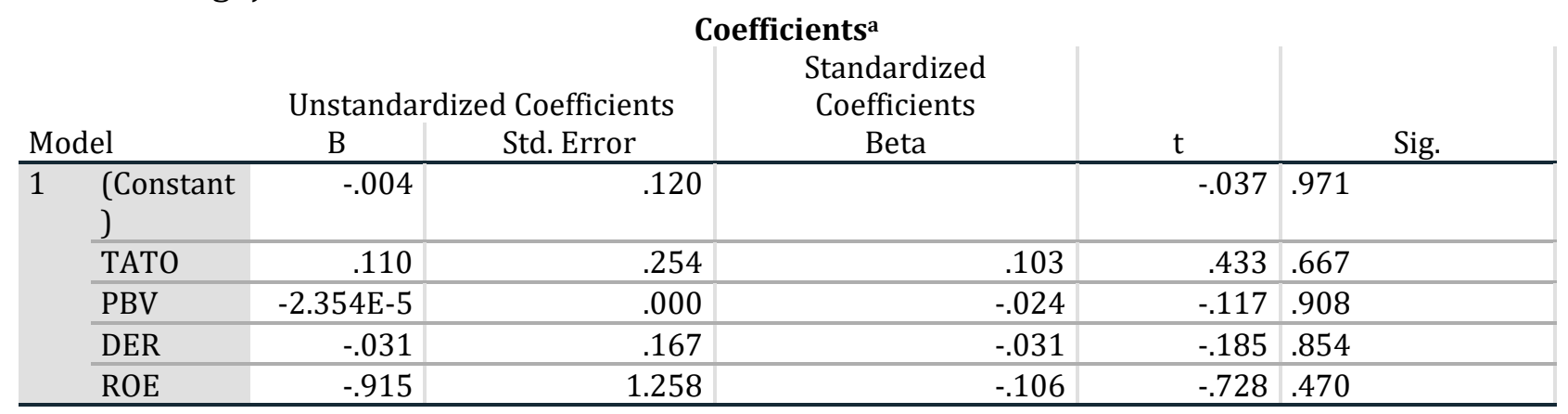

Sumber : Data Diolah

TATO $\left(\mathrm{X}_{1}\right)$ thitung $(0.433)<t_{\text {tabel }}(2.00665)$ dan nilai signifikan $0.667>0.05$ berarti $\mathrm{H}_{0}$ diterima maka $\mathrm{H}_{\mathrm{a}}$ ditolak, dengan begitu dapat dijelaskan variabel TATO secara parsial tidak memberikan pengaruh serta tidak signifikan terhadap return saham (Y). PBV (X2) thitung $(-0.117)<$ tabel $(-2.00665)$ dan hasil nilai signifikan 0.908 $>0.05$ oleh karena itu, $\mathrm{H}_{0}$ diterima maka $\mathrm{H}_{\mathrm{a}}$ ditolak berarti bisa dijelaskan variabel PBV $\left(\mathrm{X}_{2}\right)$ secara parsial tidak memberikan pengaruh serta tidak signifikan terhadap return saham $(\mathrm{Y})$. DER $\left(\mathrm{X}_{3}\right) \mathrm{t}_{\text {hitung }}(-0.185)<\mathrm{t}_{\text {tabel }}(-2.00665)$ dan hasil nilai signifikan $0.854>0,05$ oleh karena itu, $\mathrm{H}_{0}$ diterima $\mathrm{H}_{\mathrm{a}}$ ditolak artinya bisa dijelaskan DER (X $\left.\mathrm{X}_{3}\right)$ secara parsial tidak memberikan pengaruh serta tidak signifikan terhadap return saham (Y)

ROE $\left(\mathrm{X}_{4}\right)$ thitung $(-0.728)<$ tabel $(-2.00665)$ dengan signifikan $0.470>0,05$ maka $\mathrm{H}_{0}$ diterima $\mathrm{H}_{\mathrm{a}}$ ditolak, dengan demikian dijelaskan ROE $\left(\mathrm{X}_{4}\right)$ secara parsial tidak memberikan pengaruh serta tidak signifikan terhadap return saham (Y).

Uji F

Pengujian $\mathrm{F}$ digunakan dalam melihat akankah ada pengaruh TATO, PBV, DER serta ROE secara serentak pada variabel terikat. 
Tabel 9 Uji F (simultan)

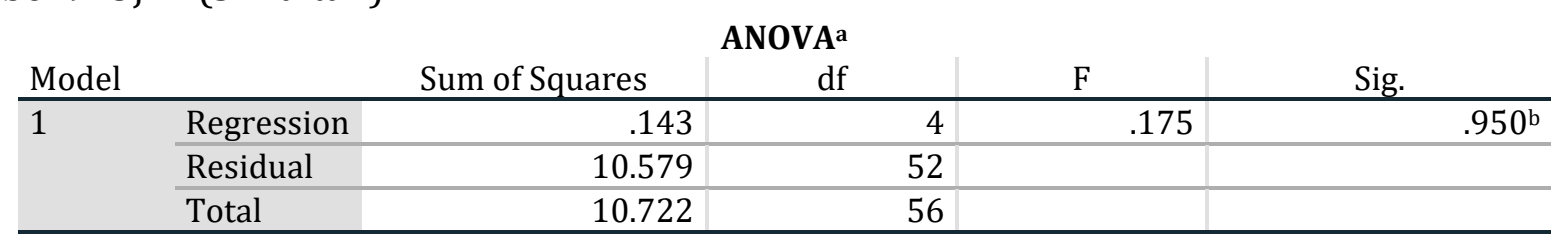

Sumber : Data Diolah

Sesuai uraian di Tabel 9 memperlihatkan diperoleh nilai Fhitung $(0.175)<$ $\mathrm{F}_{\text {tabel }}(2.55)$ dan signifikan senilai $0.950>0,05$ yang dimana $\mathrm{H}_{0}$ diterima $\mathrm{H}_{\mathrm{a}}$ ditolak, berarti TATO, PBV, DER dan ROE secara simultan tidak berpengaruh serta tidak signifikan terhadap return saham (Y) pada perusahaan restoran, hotel dan pariwisata yang terdaftar di BEI tahun 2015-2019.

\section{Pengaruh TATO Terhadap Return Saham}

Sesuai uraian analisis yang sudah dilaksanakan memperlihatkan secara parsial TATO tidak memiliki pengaruh dan tidak signifikan terhadap return saham di perusahaan restoran, hotel dan pariwisata yang terdaftar di BEI tahun 2015-2019 dimana menunjukkan TATO $\left(\mathrm{X}_{1}\right)$ thitung $(0.433)<$ tabel $(2.00665)$ dengan signifikan $0.667>0.05$ yang artinya $\mathrm{H}_{\mathrm{o}}$ diterima maka $\mathrm{H}_{\mathrm{a}}$ ditolak, dengan begitu dapat dijelaskan TATO secara parsial tidak memberikan pengaruh dan tidak signifikan terhadap Return Saham. Hasil tersebut tidak selaras pada hasil penelitian yang sudah dilaksanakan Bisara Dan Lailatul (2015) berjudul "pengaruh kinerja keuangan terhadap return saham" mengungkapkan TATO mempunyai pengaruh serta signifikan terhadap return saham.

\section{Pengaruh PBV Terhadap Return Saham}

Sesuai uraian analisis yang sudah dilaksanakan memperlihatkan variabel PBV secara parsial tidak memberikan pengaruh dan tidak signifikan terhadap Return Saham di perusahaan restoran, hotel dan pariwisata yang terdaftar di BEI tahun 2015-2019. Hasil ini tidak senada pada penelitian yang sudah dilaksanakan oleh Putri Dan Sampurno (2012) yang meneliti "analisis pengaruh ROA, EPS, NPM, dan PBV terhadap return saham (studi kasus pada industry real estate and property yang terdaftar di Bursa Efek Indonesia periode 2007-2009)" menggungkapkan price book value memberikan pengaruh serta signifikan terhadap return saham. Tidak terdapatnya hubungan PBV pada return saham memperlihatkan dimana angka PBV mencermikan nilai negatif bagi return saham yang mana sesungguhnya tingkat keberhasilan pengelolaan sumber daya perusahaan tergambar di harga saham. Semakin rendahnya nilai price book value akan semakin tidak adanya peluang kepada investor dalam memperoleh profit lebih banyak serta hilangnya kepercayaan para investor terhadap perusahaan tersebut.

\section{Pengaruh DER Terhadap Return Saham}

Sesuai uraian statistik yang sudah dilaksanakan memperlihatkan secara parsial variabel debt to eqiuty tidak memberikan pengaruh dan tidak signifikan 
terhadap return saham di perusahaan restoran, hotel dan pariwisata yang terdaftar di BEI tahun 2015-2019. Hasil ini tidak senada pada penelitian yang sudah dilaksanakan Setiyono dan Lailatul (2016) berjudul "pengaruh kinerja keuangan dan ukuran perusahaan terhadap return saham" menggungkapkan DER memberikan pengaruh serta signifikan terhadap return saham. Naiknya DER suatu perusahaan berarti meningkatkan hutang perusahaan ketimbang modal sendiri hingga berpengaruh banyak terhadap kewajiban perusahaan pada pihak luar disebabkan adanya peningkatan solvabilitas (pinjaman). Sehingga jika pihak perusahaan membayar kewajiban hutang-hutangnya semakin meningkat, maka kemampuan yang dimiliki oleh perusahaan dalam pengembalian return saham terhadap investornya akan mengalami penurunan serta membuat para investor tidak membeli saham diperusahaan tersebut.

\section{Pengaruh ROE Terhadap Return Saham}

Sesuai uraian analisis yang sudah dilaksanakan memperlihatkan ROE secara parsial tidak memberikan pengaruh dan tidak signifikan terhadap return saham diperusahaan restoran, hotel dan pariwisata yang terdaftar di BEI tahun 20152019. Hasil tersebut tidak senada pada penelitian yang sudah dilaksanakan Rajagukguk, dkk (2018) yang meneliti "pengaruh return on equity, arus kas aktivitas operasional , ukuran perusahaan dan debt to equity ratio terhadap return saham pada perusahaan yang terdaftar Indeks LQ45 di Bursa Efek Indonesia periode 20122015" menggungkapkan ROE berpengaruh serta signifikan terhadap return saham. Rasio ini memperlihatkan efisien pemanfaatan modal sendiri didalam perusahaan. Hal ini memperlihatkan return on equity yang rendah menandakan kuranngnya efisiensi suatu pengunaan modal didalam perusahaan tersebut ataupun perusahaan belum mampu memaksimalkan penggunaan modalnya dengan baik sehingga tidak menghasilkan profit. Hal ini berdampak pada return saham perusahaan disebabkan ke tidak tertarikkanya investor dalam melakukan investasi pada perusahaan itu.

\section{KESIMPULAN}

Sesuai uraian hasil pengujian hipotesis yang sudah dilakukan diperoleh kesimpulan antara lain: 1).TATO $\left(\mathrm{X}_{1}\right)$, PBV $\left(\mathrm{X}_{2}\right)$, DER $\left(\mathrm{X}_{3}\right)$, ROE $\left(\mathrm{X}_{4}\right)$ secara parsial tidak memberikan pengaruh dan tidak signifkan terhadap Return Saham (Y) pada perusahaan Restoran, Hotel dan Pariwisata yang terdaftar di Bursa Efek Indonesia tahun 2015-2019. 2). TATO $\left(X_{1}\right)$, PBV $\left(X_{2}\right)$, DER $\left(X_{3}\right)$, dan $\operatorname{ROE}\left(X_{4}\right)$ secara simultan tidak memberikan pengaruh dan tidak signifikan terhadap Return saham (Y) pada perusahaan Restoran, Hotel dan Pariwisata yang terdaftarkan di Bursa Efek Indonesia tahun 2015-2019.

\section{DAFTAR PUSTAKA}

Andasari, N.A., Kharis R., dan Rita A. (2016). Pengaruh Return On Equity (ROE), Price Earning Ratio (PER), Total Asset Turnover (TATO) dan Price Book Value 
(PBV) Terhadap Return Saham (studi kasus pada perusahaan manufaktur sektor makanan dan minuman yang terdaftar di BEI periode 2008-2014). Journal Of Accounting. Vol. 2. No. 2. Maret.

Bisara, C., dan Lailatul, A. ( 2015 ). Pengaruh Kinerja Keuangan Terhadap Return Saham. Jurnal Ilmu Dan Riset Akuntansi. Vol. 4. No. 2.

Ghozali, Iman. 2016. Aplikasi Analisis Multivariete Dengan Program IBM SPSS 23. Ed.8. Cetakan Ke VIII. Semarang: Badan Penerbit Universitas Diponegoro.

Ghozali, Iman. 2018. Aplikasi Analisis Multivariete Dengan Program IBM SPSS 25. Semarang: Badan Penerbit Universitas Diponegoro.

https://ekonomi.kompas.com/read/2018/09/27/091635126/hotel-dan-restoranjadi-investasi-favorit-untuk-pariwisata

Mandika, A. 2017. Pengaruh Informasi Laba Akuntansi Dan Arus Kas Terhadap Return Saham (studi pada perusahaan food and beverage yang terdaftar di Bursa Efek Indonesia tahun 2011-2016 ). Skripsi Fakultas Ekonomi dan Bisnis Unpas.

Muklis, F. 2016. Perkembangan Dan Tantangan Pasar Modal Indonesia. Jurnal Lembaga Keuangan Dan Perbankan. Vol 1. No.1.

Putri A. A. B., dan Sampurno, R. D. 2012. Analisis Pengaruh ROA, EPS, NPM, DER Dan PBV Terhadap Return Saham (Studi Kasus Pada Industri Real Estate And Property Yang Terdaftar Di Bursa Efek Indonesia Periode 2007-2009). Jurnal Manajemen Dan Kewirausahaan. Vol.1. No.1. September:175-180.

Rajagukguk, L., C. L. Wijono, dan Y. Pakpahan. 2018. Pengaruh Return On Equity, Arus Kas Aktivitas Operasi, Ukuran Perusahaan, Dan Debt to Equity Ratio Terhadap Return Saham Pada Perusahaan Yang Terdafatr Dalam Indeks LQ45 Di Bursa Efek Indonesia Periode 2012-2015. Jurnal Akuntansi, Auditing dan Keungan. Vol. 15. No. 1. Maret:113-143.

Sanusi, A. 2014. Metodologi Penelitian Bisnis. Cetakan Kelima. Jakarta: Salemba Empat.

Sudana, M.I., dan Putu, A. A. W (2011) Corporate Governance dan Pengungkapan Corporate Social Responbility Pada Perusahaan Go-Public Di Bursa Efek Indonesia. Jurnal Manajemen Teori dan Terapan. No.1. April. 